University of Nebraska - Lincoln

DigitalCommons@University of Nebraska - Lincoln

6-2009

\title{
Tree canopy effect on grass and grass/legume mixtures in eastern Nebraska
}

\author{
Michael El. L. Perry \\ USDA-NRCS, Minden, NE, michael.perry2@ne.usda.gov \\ Walter H. Schacht \\ University of Nebraska-Lincoln, wschacht1@unl.edu \\ Gregory A. Ruark \\ USDA-FS, Normal, AL \\ James R. Brandle \\ jbrandle1@unl.edu
}

Follow this and additional works at: https://digitalcommons.unl.edu/natrespapers

Part of the Natural Resources and Conservation Commons

Perry, Michael El. L.; Schacht, Walter H.; Ruark, Gregory A.; and Brandle, James R., "Tree canopy effect on grass and grass/legume mixtures in eastern Nebraska" (2009). Papers in Natural Resources. 168.

https://digitalcommons.unl.edu/natrespapers/168

This Article is brought to you for free and open access by the Natural Resources, School of at DigitalCommons@University of Nebraska - Lincoln. It has been accepted for inclusion in Papers in Natural Resources by an authorized administrator of DigitalCommons@University of Nebraska - Lincoln. 


\title{
Tree canopy effect on grass and grass/legume mixtures in eastern Nebraska
}

\author{
Michael E. L. Perry • Walter H. Schacht • \\ Gregory A. Ruark · James R. Brandle
}

Received: 5 April 2008/Accepted: 8 May 2009/Published online: 9 June 2009

(C) Springer Science+Business Media B.V. 2009

\begin{abstract}
A study to determine the feasibility of producing forage for grazing livestock under trees was conducted as a step toward evaluating the potential for silvopasture systems in the northern and central Great Plains. The effects of overstory leaf area index (LAI), percentage understory light transmittance (LT), and soil moisture (SM) on yield and crude protein (CP) of big bluestem [Andropogon gerardii Vitman; (BB)], smooth bromegrass [Bromus inermis Leyss.; (SB)], and mixtures with birdsfoot trefoil [Lotus corniculatus L.; (BFT)] were examined. The study was conducted in both Scotch pine (Pinus sylvestris L.) and green ash
\end{abstract}

At the time of the research, the senior author was research assistant, Department of Agronomy and Horticulture, University of Nebraska-Lincoln, Lincoln, NE 68853-0915.

M. E. L. Perry $(\bowtie)$

USDA-Natural Resource Conservation Service, Minden

Field Office, 1005 South Brown Ave, Minden,

NE 68959-2601, USA

e-mail: michael.perry2@ne.usda.gov

\section{W. H. Schacht}

Department of Agronomy and Horticulture, University

of Nebraska-Lincoln, Lincoln, NE 68583-0915, USA

G. A. Ruark

USDA National Agroforestry Center, Normal,

AL 35762, USA

J. R. Brandle

School of Natural Resources, University

of Nebraska-Lincoln, Lincoln, NE 68583, USA
(Fraxinus pennsylvancia Marsh.) tree plantations, at the University of Nebraska Agriculture Research and Development Center near Mead, Nebraska. Thirty-six plots representing a wide range of canopy cover were selected at each location and seeded in April 2000 to $\mathrm{BB}, \mathrm{SB}$, or mixtures with BFT. Measurements of LAI, LT, and SM were taken throughout the 2001-growing season and plots were harvested in June and September 2001. Soil moisture generally did not explain much of the variability in yield or $\mathrm{CP}$ for $\mathrm{BB}, \mathrm{SB}$, or BFT. Cumulative LAI or LT averaged over the growing season was the best predictor of yield or CP, particularly under the pine. Yields of BB and SB increased as LAI decreased or LT increased. Conversely, the CP of $\mathrm{BB}$ and SB increased as LT decreased for both the June and September harvests. Both BB and SB maintain relatively high productivity under partial shading; however, BFT yields were low at LT levels below $75 \%$.

Keywords Andropogon gerardii Vitman . Bromus inermis Leyss. - Leaf area index . Light transmittance - Lotus corniculatus L. . Silvopasture

\section{Introduction}

Silvopasture is a type of agroforestry that intentionally combines trees, forage crops, and livestock production into a structural system of planned interactions. These 
are managed intensively to produce simultaneously wood products, high quality forage, and livestock on an environmentally sustainable basis (Clason and Sharrow 2000). A silvopasture system provides an overall greater economic return for the landowner per hectare than either timber or cattle alone (Pearson and Whitaker 1974; Clason 1995; Gold et al. 2000). In the United States, the majority of research with silvopasture systems has been conducted in the southeast and northwest, and has focused on forage and/or animal performance under various canopy covers of different conifer tree species or the forage response to different light levels, whether imposed by shade cloth or tree canopy (Pearson and Whitaker 1974; Garrett and Kurtz 1983; Lewis et al. 1985; Kephart et al. 1992; Kephart and Buxton 1993).

Most warm-season grasses utilize the $\mathrm{C}_{4}$ photosynthetic pathway of carbon fixation whereas cool-season grasses use the $C_{3}$ pathway (Waller and Lewis 1979). The $\mathrm{C}_{4}$ species are adapted to full sunlight and generally possess a higher light saturation point, higher photosynthetic capacity, and show a greater reduction in photosynthetic capacity under shade than $\mathrm{C}_{3}$ species (Björkman 1981). At light saturation, $\mathrm{C}_{3}$ grasses have a maximum photosynthetic rate about one-half that of $\mathrm{C}_{4}$ grasses (Moser and Hoveland 1996). Cool-season plants generally respond to shade by investing a greater proportion of synthetic capacity into increasing overall leaf chlorophyll content (Boardman 1977), whereas warm-season plants respond by increasing specific leaf area (Murchie and Horton 1997). Even with greater specific leaf area, shaded leaves of $\mathrm{C}_{4}$ plants intercept less light than full sunlight leaves and net photosynthesis declines because of low irradiance (Kephart et al. 1992).

Forage quality is modified by the plant environment, and temperature and soil moisture may have a more profound effect on overall quality than light flux (Buxton and Fales 1994; Henderson and Robinson 1982). Shading, with the associated lower temperatures, however, may cause lower cell wall concentrations and increased nutrient content because of slower rate of plant maturity (Allard et al. 1991; Kephart and Buxton 1993). Soil water deficiency also can have a positive influence on forage quality (Misra and Singh 1982; Wilson 1983). Seasonal water deficits generally slow the rate of plant maturity, and dry matter (DM) production, thereby increasing the nutrient content and digestibility of plant tissue.
Forage production in silvopasture systems with different tree canopy covers has not been documented in the eastern prairie region of the Great Plains. Warm-season grasses may not be well suited for understory conditions because of their high light requirements, but big bluestem (Andropogon gerardii Vitman; BB), a common native warm-season grass, is adapted to a wide range of environments (Stubbendieck et al. 1997). In the tall-grass prairie in the eastern Great Plains, BB is the most abundant and highest-quality species present in good to excellent condition range (Moser and Vogel 1995). Of the tall grasses found in Nebraska, BB is the most shade tolerant (Weaver 1965). Cool-season grasses that are shade tolerant and well adapted to the eastern Great Plains, such as smooth bromegrass (Bromus inermis Leyss.; SB), appear to be excellent candidates. Smooth bromegrass is adapted to many environments and soil types and tolerates moderate shade conditions (Fulbright et al. 1982; Lin et al. 1999). Smooth bromegrass is highly palatable, is high in crude protein $(\mathrm{CP})$ content, relatively low in fiber and produces excellent hay for livestock and fall regrowth may produce enough biomass for fall grazing programs (Casler and Calrson 1995; Stubbendieck et al.1997). Legumes are important components of pastures because of positive impacts on forage quality and quantity as well as providing soil nitrogen (N). Birdsfoot trefoil (Lotus corniculatus L.; BFT) is a legume adapted to a wide range of environmental conditions and is used commonly in grass/legume mixtures in the central and northern Great Plains. Birdsfoot trefoil can tolerate many growing conditions, can grow where soil properties or environmental conditions make alfalfa production difficult, and will grow under drought conditions (Beuselinck and Grant 1995; Undersander et al. 1993). The nutritive value of BFT has been suggested to be equal to or greater than that of alfalfa (Langilee and Calder 1971; Marten and Jordan 1979). The purpose of this study was to evaluate tree and forage species common to the central Great Plains, as to their potential in silvopasture systems.

The objective of this study was to determine dry matter yield and CP content of seeded understory forage species in response to a range of overstory leaf area or percentage understory light transmittance (LT), and their interactions with soil moisture. 


\section{Materials and methods}

\section{Study area}

The study was conducted in two tree plantations at the University of Nebraska Agricultural Research and Development Center (ARDC) near Mead, Nebraska in 2001. The tree plantations were a stand of Scotch pine (Pinus sylvestris L.) trees $\left(96^{\circ} 33^{\prime} \mathrm{W}, 41^{\circ} 11^{\prime} \mathrm{N}\right.$, and $315 \mathrm{~m}$ elevation) and green ash (Fraxinus pennsylvancia Marsh.) trees $\left(96^{\circ} 30^{\prime} \mathrm{W}, 41^{\circ} 08^{\prime} \mathrm{N}\right.$, and $366 \mathrm{~m}$ elevation). The prominent soil type at the Scotch pine location is a Tomek silt loam (fine, smectitic, mesic Pachic Argiudolls) of loess origin; whereas, the soils of the green ash location are of loess origin and consists of Filbert silt loams (fine, smectitic, mesic Vertic Argialbolls) and Tomek silt loams (fine, smectitic, mesic Pachic Argiudolls). The soils at both locations are relatively fertile with $\mathrm{pH}$ ranging from 6.04 to 6.63 and organic matter content of the topsoil between 2.55 and $4.43 \%$ (Perry 2004). The long-term (1968-2001) mean annual precipitation was $675 \mathrm{~mm}$ with about $75 \%$ coming during the growing season, April through September (HPRCC 2002; Table 1). The precipitation in 2000 and 2001 was 587 and $695 \mathrm{~mm}$, respectively. Rainfall amount for May 2001 (233 mm) exceeded the 31-year longterm average for this month $(107 \mathrm{~mm})$, with $137 \mathrm{~mm}$ falling the first 5 days of the month. Average temperatures from May through September in 2000 and 2001 were 21.4 and $21.1^{\circ} \mathrm{C}$, respectively, and were near the long-term (1968-2001) average of $20.8^{\circ} \mathrm{C}$ (HPRCC 2002). The first killing frost of fall 2000 was October 5, 2000, and the last of 2001 was April 24, 2001.
The Scotch pine trees were planted at a spacing of $6.1 \times 6.1 \mathrm{~m}$ in 1971 and 1972 as a seed orchard with branches grafted from various sources. Trees had been pruned most recently in winter 1989/1990. Canopy cover of the Scotch pine location was relatively uniform, except where groups of trees had died, resulting in scattered openings. Tree basal diameters ranged from 18 to $76 \mathrm{~cm}$. The understory was not seeded at tree planting, and no effort was made to control the establishment of invading species. Smooth bromegrass and tall fescue (Festuca arundinacea, Schreb.) were the principal plant species under dense canopy cover and transition areas, while the open areas were dominated by green foxtail [Setaria viridis (L.) Beauv]. The most common understory forb was creeping woodsorrel (Oxalis corniculata L.).

A site was selected at the Scotch pine location that included an open area with little to no overhead canopy, a dense canopy of trees, and an area of intermediate canopy density. There were no trees in the open area but branches of the neighboring trees partially shaded the area, especially on the south side. Thirty-six contiguous plots were located within this site with 12 plots each in the open area, in the dense canopy area, and in the intermediate canopy area. Each plot measured $3.0 \times 4.6 \mathrm{~m}$. In mid-summer 2001, average plot LAI ranged from 0 in the plots of the open area (although the LAI of some plots was as high as $0.5-1.0$ because of surrounding trees) to 5.3 in dense canopy plots. Basal area of trees in the intermediate and dense canopy areas was as high as $30 \mathrm{~m}^{2} \mathrm{ha}^{-1}$.

The green ash trees were from sources throughout the Great Plains. They were planted at a spacing of

Table 1 Monthly meteorological measurements for the Agricultural Research and Development Center near Mead, NE, 2001

\begin{tabular}{clllll}
\hline Month & $\begin{array}{l}\text { Maximum } \\
\text { temperature }\left({ }^{\circ} \mathrm{C}\right)\end{array}$ & $\begin{array}{l}\text { Minimum } \\
\text { temperature }\left({ }^{\circ} \mathrm{C}\right)\end{array}$ & $\begin{array}{l}\text { Relative } \\
\text { humidity }(\%)\end{array}$ & $\begin{array}{l}\text { Solar radiation } \\
\left(\mathrm{MJ} / \mathrm{m}^{2}\right)\end{array}$ & $\begin{array}{l}\text { Total precipitation } \\
(\mathrm{mm})\end{array}$ \\
\hline $\begin{array}{r}\text { Monthly averages } \\
\text { Mar }\end{array}$ & & & & & \\
Apr & 1.05 & -3.77 & 81.9 & 12.1 & 20.0 \\
May & 23.4 & 4.43 & 66.4 & 15.7 & 55.0 \\
June & 27.7 & 11.1 & 65.9 & 16.4 & $233.0^{\mathrm{a}}$ \\
July & 31.4 & 14.9 & 68.7 & 21.0 & 42.0 \\
Aug & 30.3 & 19.2 & 78.9 & 19.1 & 5.58 \\
Sept & 24.8 & 16.6 & 74.6 & 19.9 & 58.4 \\
\hline
\end{tabular}

${ }^{a}$ In May $137 \mathrm{~mm}$ of rainfall was recorded in the first 5 days of the month 
$3.7 \mathrm{~m}$ in 1981 at the ARDC as part of a drought resistance study. The understory was seeded to 'KY31' tall fescue following tree establishment. Tree canopy cover within the stand varied greatly because of variable tree size and death of some trees since planting. Tree basal diameters ranged from 3.3 to $28 \mathrm{~cm}$. Existing differences in tree density and growth were used in selecting areas of low, intermediate, and dense tree canopy cover in August 1999. Within each area, there were 12 contiguous plots $(3.7 \times 3.7 \mathrm{~m})$ with a tree at each corner. In midsummer 2001, average plot LAI and basal area of the trees at plot corners ranged from 1.7 and $5.7 \mathrm{~m}^{2} \mathrm{ha}^{-1}$ in low canopy plots to 2.7 and $11 \mathrm{~m}^{2} \mathrm{ha}^{-1}$ in dense canopy plots, respectively.

\section{Experiment layout}

Each of four different grass/legume mixtures was allocated randomly to three of the 12 plots within each of the canopy cover areas at the two locations. The mixtures were BB, BB/BFT, SB, and SB/BFT. Preparation of plots for seeding began in September 1999 when all understory vegetation was sprayed with glyphosate (4-amino-3,5,6-trichloropicolinic acid) at a rate of $1.1 \mathrm{~kg}$ a.i. ha ${ }^{-1}$ using a backpack sprayer. Prescribed fire was used in late March 2000 to remove all aboveground herbaceous plant material and suppress cool-season plants that had begun to grow. The plots were rototilled in early April to prepare a seedbed for seeding in mid-April. Big bluestem was seeded at $5.6 \mathrm{~kg}$ pure live seed (PLS) ha ${ }^{-1}$; and SB was seeded at $8.9 \mathrm{~kg}$ PLS ha ${ }^{-1}$. Big bluestem and SB were seeded at the same rates in mixtures with BFT which was seeded at $6.7 \mathrm{~kg} \mathrm{ha}{ }^{-1}$.

Plots were irrigated twice weekly in May and June 2000 to ensure stand establishment. Weed density was high in 2000. To minimize the effect of weeds on stand establishment, each plot was hand-weeded once in June and July. Plots were not weeded or irrigated in 2001. Plots were mowed to a height of $7.6 \mathrm{~cm}$ in April 2001 to remove dead plant material before the second growing season.

\section{Measurements and laboratory analysis}

In each plot, LAI of the tree canopy was estimated using the LI-COR LAI-2000 plant canopy analyzer (LI-COR Incorporated, Lincoln, NE). Measurements were taken on a monthly basis from May through August 2001. All LAI measurements were taken on cloudy mornings or at dawn when the azimuth angle of the sun was no greater than $76^{\circ}$ (Gower and Norman 1991). Measurements were taken at $1.0 \mathrm{~m}$ above the soil surface from each corner of a plot, facing the opposite corner. Reference measurements were taken two or more times on each collection day in an open field near each location. To mask out the operator, an opaque cover to restrict the viewing area to $45^{\circ}$ or $90^{\circ}$ was placed over the LAI sensor at the Scotch pine or green ash locations, respectively. The LAI data were downloaded to a computer following each collection period and processed using the $\mathrm{C} 2000$ program provided by LI-COR to correct the LAI values with respect to reference readings.

Percentage understory light transmittance was calculated following the method described by Constabel and Lieffers (1996). Measurements were taken on a monthly basis from May through August near solar noon (between 1,200 and 1,400 h). When possible, LT was measured within a few days of the LAI measurements. The LT measurements were taken on days with few or no clouds. Measurements were taken at $1.5 \mathrm{~m}$ above the soil surface in eight directions (cardinal and ordinal) from the center of each plot. Data collection per plot took approximately $30 \mathrm{~s}$. The data were downloaded to a computer following each collection period. The eight data points per plot were averaged together then matched up with the LI-190SA Quantum Sensor data that was closest in time to determine \% understory LT. Percentage understory LT was calculated by dividing the understory PAR readings for each plot by the unattenuated PAR readings (Constabel and Lieffers 1996) taken in the open.

Soil moisture (SM) was estimated with the Trase Time Domain Reflectrometry (TDR) System Model 6050X1 (Soil Moisture Equipment Corp., Santa Barbara, CA). Soil moisture was measured at the center of each plot at depth intervals of $0-15 \mathrm{~cm}$, 0-30 cm, 0-45 cm, and 0-60 cm using stainless steel rods. Rods were installed and remained for the duration of the study; however, the $15-\mathrm{cm}$ depth interval was measured by inserting a pair of $15-\mathrm{cm}$ rods into the soil at the time of measurement. Soil moisture measurements were taken from April through July and were made in conjunction with LAI and LT measurements (Table 2). 
Table 2 Number of observations $(N)$, mean, and standard deviation (SEM) of \% soil moisture content measurements from 2001

\begin{tabular}{|c|c|c|c|c|c|c|}
\hline \multirow[t]{2}{*}{ Depth increment $(\mathrm{cm})$} & \multicolumn{3}{|c|}{ Scotch pine } & \multicolumn{3}{|c|}{ Green ash } \\
\hline & $N$ & Mean & SEM & $N$ & Mean & SEM \\
\hline \multicolumn{7}{|c|}{ Soil moisture content $(\%)^{\mathrm{a}}$} \\
\hline April $0-15$ & - & - & - & 35 & 32.2 & 0.52 \\
\hline May $0-15$ & $36^{\mathrm{b}}$ & 25.9 & 0.41 & 35 & 25.8 & 0.58 \\
\hline June SM 0-15 & 36 & 27.3 & 0.52 & 35 & 31.8 & 0.41 \\
\hline July SM 0-15 & 35 & 17.3 & 0.41 & $35^{\mathrm{b}}$ & 23.5 & 0.55 \\
\hline April $0-30$ & - & - & - & 32 & 33.4 & 0.25 \\
\hline May 0-30 & $36^{\mathrm{b}}$ & 29.0 & 0.31 & 32 & 28.4 & 0.41 \\
\hline June SM 0-30 & 36 & 26.1 & 0.49 & 32 & 26.3 & 0.46 \\
\hline July SM 0-30 & 36 & 18.5 & 0.34 & $32^{\mathrm{b}}$ & 21.1 & 0.46 \\
\hline April $0-45$ & - & - & - & 32 & 33.8 & 0.40 \\
\hline May $0-45$ & $36^{\mathrm{b}}$ & 30.4 & 0.26 & 32 & 30.0 & 0.48 \\
\hline June SM 0-45 & 36 & 27.5 & 0.40 & 32 & 27.7 & 0.50 \\
\hline July SM 0-45 & 36 & 19.9 & 0.36 & $32^{\mathrm{b}}$ & 20.6 & 0.64 \\
\hline April 0-60 & - & - & - & 32 & 35.4 & 0.62 \\
\hline May SM 0-60 & $36^{\mathrm{b}}$ & 33.0 & 0.98 & 32 & 32.9 & 1.07 \\
\hline June SM 0-60 & 35 & 31.2 & 1.33 & 32 & 30.4 & 1.19 \\
\hline July SM 0-60 & 23 & 20.5 & 0.86 & $32^{\mathrm{b}}$ & 20.6 & 0.73 \\
\hline
\end{tabular}

a Percentage soil moisture was a volumetric measurement

b Soil moisture measurements were taken twice during the month, but were averaged together

Above-ground yields were estimated in all plots in early June 2001 and mid-September 2001 using a quadrat method. The June and September sampling dates coincided with the reproductive stage of $\mathrm{BB}$ and SB, respectively. To avoid sampling a point in a plot more than once, quadrat $(25 \times 100 \mathrm{~cm})$ locations were identified within each plot and marked with flags before the first sampling date. At each sampling date, vegetation in each quadrat was clipped at ground level, separated into plant groups (i.e., BB, $\mathrm{SB}$, BFT, or non-seeded species), and placed in separate paper bags.

Samples were dried in a forced-air oven at $60^{\circ} \mathrm{C}$ to a constant dry weight. After drying, BB and SB plants from each bag were separated into leaf and stem fractions. Leaf blades were separated at the collar, and the sheaths remained with the stems. The leaf fraction and stem fraction for each grass species from each quadrat were weighed and then composited by plot. The BFT bags also were composited for each plot. Composited samples were ground initially using a Wiley mill (Arthur Thomas Co., Philadelphia, PA) fitted with a 2-mm screen. Later, samples were ground using a cyclone mill (Udy Analyzer Company, Boulder, CO) fitted with a 1-mm screen in preparation for forage quality analysis. The nitrogen (N) content of each sample was estimated using a FP$428 \mathrm{~N}$ determination system 601-700-300 (Leco Corporation, St. Joseph, MI) in the University of Nebraska-Lincoln Soil and Plant Analysis Laboratory. The $\mathrm{N}$ content of each sample was then converted to $\mathrm{CP}$ using the conversion factor of 6.25 .

Data analysis

Data from the two locations in 2001 were analyzed separately. Multiple linear regression analysis was used to model the dependent variables (i.e., dry matter yield or $\mathrm{CP}$ ) as a function of the independent variables (i.e., LAI, LT, or SM). Leaf area index and LT were analyzed separately in model development. Soil moisture was tested as a significant variate in model development with LAI and LT separately. Analyses were conducted using a manual selection of significant variables from the variance table in the GLM procedure of SAS (SAS Institute Inc 1999) at $\alpha=0.05$ level. The BFT data were omitted from the analysis of the June and September harvests at the green ash location because establishment was poor and sporadic.

An average of each independent variable over the sampling dates was used as another independent variable in the analysis. The average LAI (AVGLAI), LT (AVGLT), and SM (AVGSM) measurements for the June harvest at both locations included sampling dates in May and June. Soil moisture was measured in April at the green ash, but plots were wet and inaccessible at the Scotch pine in April. Average measurements for the September harvest at both locations included sampling dates from May through August; however, SM measurements at the Scotch pine location included only May, June, and July measurements, whereas, April was included at the green ash location.

In the interpretation of interactions, only interactions between light variables and SM within the same month or averaged over the same months were examined. Interactions between light variables and SM were graphed using the dependent variable as a function of the changing light levels while SM was 
held constant. The constant SM values were the maximum, mean, and minimum SM values specific to the plant species and sampling dates. To assist in interpreting the interactions involving the SM data, soil field capacity (FC) and permanent wilting point (PWP) at both locations were estimated based on soil textural analysis using the Decision Support System for Agrotechnology Transfer (DSSAT) program (Hunt et al. 1994; Jones et al. 1998).

\section{Results and discussion}

Scotch pine location

\section{Grass and BFT yields}

Variability of BB June yields was not effectively explained by May and June light conditions. Yields of BB were relatively low in June (Table 3) because BB growth did not begin until the later half of May; consequently, the overstory canopy did not have a significant impact on June BB yields. September BB yields were explained largely by AVGLT, as an integration of growing season light conditions (Fig. 1). Yield of BB ranged from 0.82 to 1.0 $\mathrm{Mg} \mathrm{DM} \mathrm{ha}{ }^{-1}$ between 20 and $75 \%$ LT. Yield at full sunlight was over two times greater than that at 20-75\% LT range. An inverse polynomial model was analyzed and found to fit the data well. The rapidly increasing BB yield at higher LT agrees with the findings of Kephart et al. (1992) and Lin et al. (1999), although they reported points of inflection at lower light levels than what we found. The relationship described in Fig. 1 was substantiated by other significant relationships between light and September yield regardless of light (LAI or LT) and month (Table 4, Eqs. 2-8). These responses showed a relatively flat line between 20 and $75 \%$ LT and LAI levels of 2-5.

Variability in SB yields in June and September was explained by light conditions and the relationship between yield and LT was linear; however, the full range of LT was not analyzed for SB. All SB plots located in the open area were partially shaded by surrounding trees and LT did not exceed $75 \%$

Table 3 Yields (Mg DM ha ${ }^{-1}$ ) in June and September 2001 at the Scotch pine and green ash locations for big bluestem (BB), smooth bromegrass (SB), and birdsfoot trefoil (BFT)

\begin{tabular}{|c|c|c|c|c|c|c|c|}
\hline \multirow[t]{2}{*}{ Treatment } & \multirow[t]{2}{*}{ Species } & \multicolumn{3}{|l|}{ June harvest } & \multicolumn{3}{|c|}{ September harvest } \\
\hline & & $\begin{array}{l}\text { Range } \\
\left(\mathrm{Mg} \mathrm{DM} \mathrm{ha}^{-1}\right)\end{array}$ & $\begin{array}{l}\text { Mean } \\
\left(\mathrm{Mg} \mathrm{DM} \mathrm{ha}^{-1}\right)\end{array}$ & $\begin{array}{l}\text { SEM } \\
\left(\mathrm{Mg} \mathrm{DM} \mathrm{ha}^{-1}\right)\end{array}$ & $\begin{array}{l}\text { Range } \\
\left(\mathrm{Mg} \mathrm{DM} \mathrm{ha}^{-1}\right)\end{array}$ & $\begin{array}{l}\text { Mean } \\
\left(\mathrm{Mg} \mathrm{DM} \mathrm{ha}^{-1}\right)\end{array}$ & $\begin{array}{l}\text { SEM } \\
\left(\mathrm{Mg} \mathrm{DM} \mathrm{ha}^{-1}\right)\end{array}$ \\
\hline \multicolumn{8}{|l|}{ Scotch pine } \\
\hline BB & BB & $0.22-1.5$ & 0.61 & 0.16 & $0.72-2.6$ & 1.2 & 0.26 \\
\hline \multirow[t]{3}{*}{$\mathrm{BB} / \mathrm{BFT}$} & BB & $0.04-0.74$ & 0.32 & 0.08 & $0.39-0.80$ & 0.59 & 0.05 \\
\hline & BFT & $0.01-0.99$ & 0.31 & 0.12 & $<0.01-0.99$ & 0.34 & 0.01 \\
\hline & Total & $0.09-1.6$ & 0.63 & 0.19 & $0.43-1.8$ & 0.93 & 0.16 \\
\hline SB & SB & $0.09-1.4$ & 0.81 & 0.14 & $0.17-1.4$ & 0.96 & 0.13 \\
\hline \multirow[t]{3}{*}{$\mathrm{SB} / \mathrm{BFT}$} & SB & $0.12-1.7$ & 0.67 & 0.17 & $0.20-1.7$ & 0.76 & 0.13 \\
\hline & BFT & $<0.01-1.4$ & 0.25 & 0.16 & $<0.01-1.3$ & 0.30 & 0.20 \\
\hline & Total & $0.13-2.0$ & 0.92 & 0.22 & $0.20-2.0$ & 1.1 & 0.25 \\
\hline \multicolumn{8}{|l|}{ Green ash } \\
\hline BB & BB & $0.87-2.0$ & 1.4 & 0.11 & $1.3-2.1$ & 1.6 & 0.08 \\
\hline \multirow[t]{3}{*}{$\mathrm{BB} / \mathrm{BFT}$} & BB & $0.36-0.97$ & 0.64 & 0.07 & $0.62-2.0$ & 1.2 & 0.16 \\
\hline & BFT & $<0.01-1.1$ & 0.47 & 0.14 & $<0.01-1.5$ & 0.48 & 0.19 \\
\hline & Total & $0.45-1.8$ & 1.1 & 0.13 & $0.99-2.8$ & 1.7 & 0.22 \\
\hline SB & SB & $0.98-1.9$ & 1.5 & 0.09 & $1.4-2.0$ & 1.6 & 0.07 \\
\hline \multirow[t]{3}{*}{$\mathrm{SB} / \mathrm{BFT}$} & SB & $0.94-1.9$ & 1.4 & 0.09 & $1.4-1.8$ & 1.6 & 0.05 \\
\hline & BFT & $<0.01-1.3$ & 0.33 & 0.15 & $0.01-0.56$ & 0.19 & 0.07 \\
\hline & Total & $0.94-2.6$ & 1.8 & 0.18 & $1.4-2.1$ & 1.8 & 0.07 \\
\hline
\end{tabular}




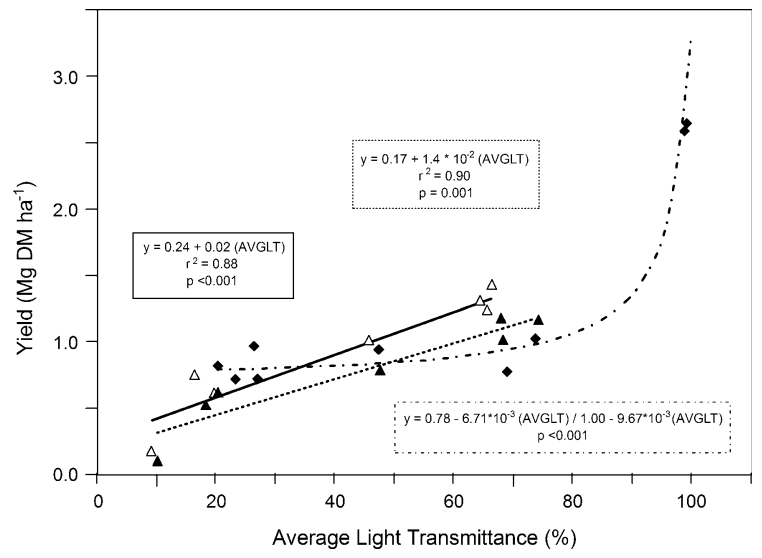

Fig. 1 Fitted curves for yield of big bluestem $(B B)$ in September (Sept, $-\downarrow$ ) from monoculture plots, and smooth bromegrass $(S B)$ in June $(\boldsymbol{\Delta}-\boldsymbol{\Lambda})$ and Sept $(\Delta-\Delta)$ from monoculture plots, at the Scotch pine location, in response to average light transmittance $(A V G L T)$

(Fig. 1). The increasing SB yields with increased light levels were in accordance with other studies that reported linear increases of cool-season grasses as light levels increased (Kephart et al. 1992; Lin et al. 1999).

June yields of BFT in the SB/BFT plots were correlated to LAI measurements taken on 4 June 2001 (Table 4, Eq. 20). Yield of BFT increased on average by $0.24 \mathrm{Mg} \mathrm{DM} \mathrm{ha}^{-1}$ as LAI decreased by increments of 0.5 between levels of 3.0 and 1.0; whereas, BFT yield remained near 0 from LAI levels of 3.05.0. Poor yield response of legumes to low light intensity has been reported in other studies (Lin et al. 1999; McGraw et al. 2008). June BFT yields in the $\mathrm{BB} / \mathrm{BFT}$ plots were not correlated to LAI or LT. September BFT yields in the BB/BFT and SB/BFT plots increased linearly as AVGLT increased. September yields of BFT in the BB/BFT and SB/BFT plots increased by 0.15 or $0.12 \mathrm{Mg} \mathrm{ha}^{-1}$, respectively, with each $10 \%$ increase in AVGLT (Table 4, Eqs. 11 and 23). Total yield in the BB/BFT and SB/ BFT plots generally increased linearly as AVGLT increased (data not shown).

\section{Grass and BFT CP}

Leaf and stem CP of BB in the BB plots in June and September (Table 5) were correlated to light conditions and increased as light levels decreased. The quadratic response of June $\mathrm{CP}$ of $\mathrm{BB}$ leaves to
AVGLT (Fig. 2) demonstrated that CP of BB leaves remained above $150 \mathrm{~g} \mathrm{~kg}^{-1}$ at low to moderate levels of LT $(<75 \%)$, but decreased to $110 \mathrm{~g} \mathrm{~kg}^{-1}$ at full sunlight. June $\mathrm{CP}$ of $\mathrm{BB}$ stems in the BB plots was not correlated to LAI or LT as main effects. In September, CP of BB leaves and stems in the BB plots decreased by 4.5 and $2.3 \mathrm{~g} \mathrm{~kg}^{-1}$, respectively, as the AVGLT increased by $10 \%$ (Fig. 2). The CP of BB leaves and stems in the BB plots in September was predicted to increase by 4.7 and $2.5 \mathrm{~g} \mathrm{~kg}^{-1}$, respectively, as AVGLAI increased by increments of 0.5 (Fig. 3).

The relationship between light and the CP of SB leaves and stems in June and September were similar to those previously described for the $\mathrm{CP}$ of $\mathrm{BB}$ leaves and stems. June CP of SB leaves was not correlated to LAI or LT as main effects. The CP of SB leaves and stems in September increased as LT decreased or overstory LAI increased. In September there was a quadratic relationship between $\mathrm{CP}$ of SB leaves and AVGLAI in the SB plots (Fig. 3). The response with AVGLAI demonstrated that CP of SB leaves at LAI levels below 0.5 almost reached $80 \mathrm{~g} \mathrm{~kg}^{-1}$, but CP remained above $250 \mathrm{~g} \mathrm{~kg}^{-1}$ when the overstory LAI was greater than 3.0. The response of leaf $\mathrm{CP}$ to light levels corresponds with other studies (Allard et al. 1991; Kephart and Buxton 1993; Lewis et al. 1983). Although shading appears to have a positive influence on tissue CP content, shading is commonly reported to lower soluble carbohydrate level in plants contributing to a decline in herbage dry matter digestibility (Wilson 1984; Buxton and Casler 1993).

Crude protein content of BFT did not appear to respond to light level. The lack of variability was probably related to poor stand establishment and the absence of plant material over the full range of light levels for proper $\mathrm{CP}$ analysis.

Green ash location

\section{Grass and BFT yields and CP}

The average June and September yields of BB and SB were greater than the observed yields at the Scotch pine location (Table 1); however, BFT yields were similar at both locations. The difference in average yield between the two locations likely was related to the denser overstory of the Scotch pine trees. The relationship between yield of $\mathrm{BB}$ or $\mathrm{SB}$ in 


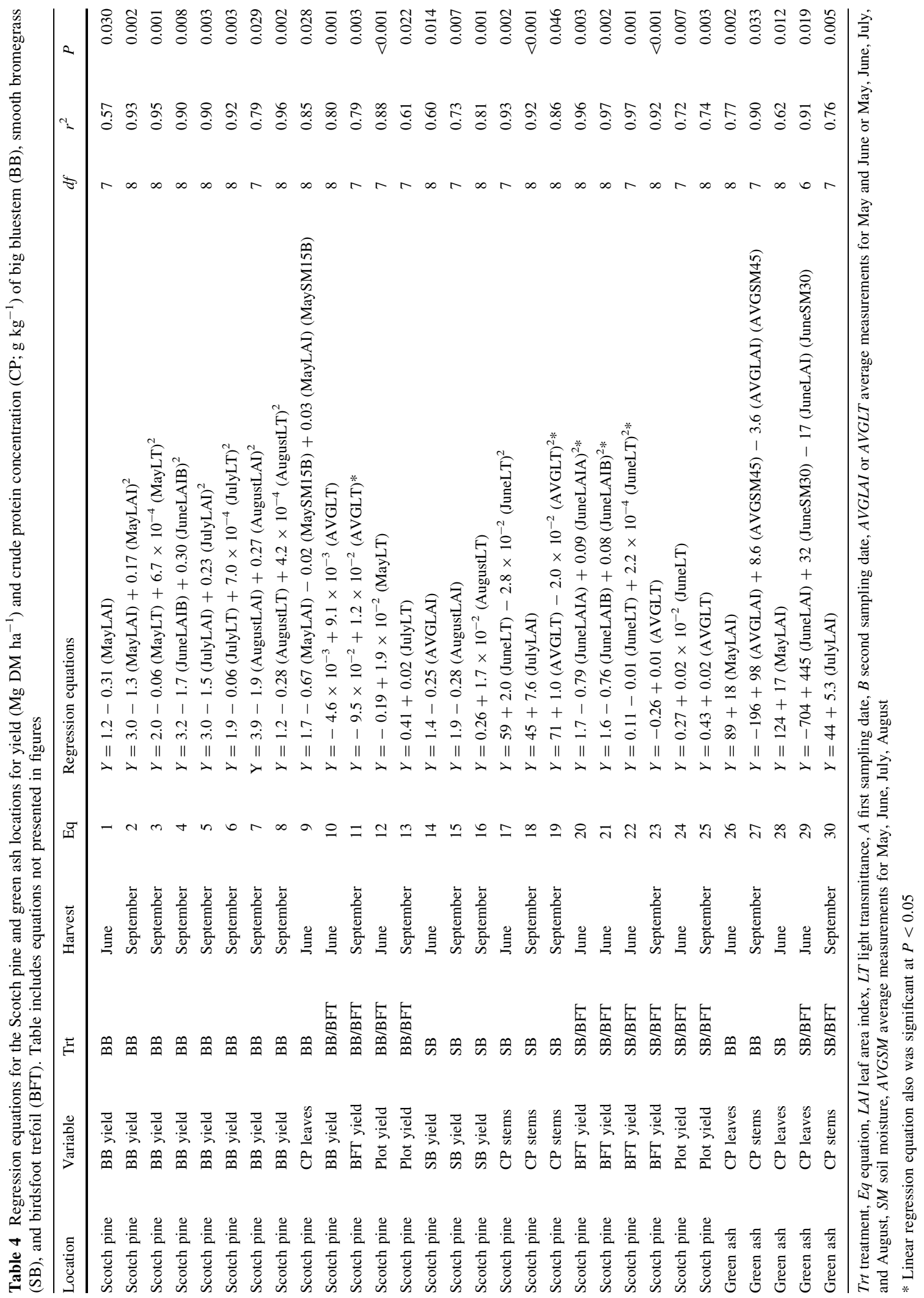


Table 5 Leaf and stem crude protein (CP) concentrations $\left(\mathrm{g} \mathrm{kg}^{-1}\right)$ in June and September 2001 at the Scotch pine and green ash locations for big bluestem (BB), smooth bromegrass (SB), and birdsfoot trefoil (BFT)

\begin{tabular}{|c|c|c|c|c|c|c|c|}
\hline \multirow[t]{2}{*}{ Treatment } & \multirow[t]{2}{*}{ Species } & \multicolumn{3}{|c|}{ June harvest } & \multicolumn{3}{|c|}{ September harvest } \\
\hline & & $\begin{array}{l}\text { Range } \\
\left(\mathrm{g} \mathrm{kg}^{-1}\right)\end{array}$ & $\begin{array}{l}\text { Mean } \\
\left(\mathrm{g} \mathrm{kg}^{-1}\right)\end{array}$ & $\begin{array}{l}\text { SEM } \\
\left(\mathrm{g} \mathrm{kg}^{-1}\right)\end{array}$ & $\begin{array}{l}\text { Range } \\
\left(\mathrm{g} \mathrm{kg}^{-1}\right)\end{array}$ & $\begin{array}{l}\text { Mean } \\
\left(\mathrm{g} \mathrm{kg}^{-1}\right)\end{array}$ & $\begin{array}{l}\text { SEM } \\
\left(\mathrm{g} \mathrm{kg}^{-1}\right)\end{array}$ \\
\hline \multicolumn{8}{|l|}{ Scotch pine } \\
\hline \multirow[t]{2}{*}{$\mathrm{BB}$} & BB leaves & $106-170$ & 145 & 7.0 & $69-110$ & 94 & 5.3 \\
\hline & BB stems & $60-118$ & 87 & 6.7 & $31-53$ & 44 & 3.0 \\
\hline \multirow[t]{3}{*}{$\mathrm{BB} / \mathrm{BFT}$} & BB leaves & $135-165$ & 148 & 4.2 & $95-124$ & 109 & 2.7 \\
\hline & BB stems & $75-106$ & 90 & 4.2 & $45-59$ & 50 & 2.0 \\
\hline & $\mathrm{BFT}^{\mathrm{a}}$ & $149-224$ & 181 & 9.9 & $101-155$ & 134 & 8.3 \\
\hline \multirow[t]{2}{*}{ SB } & SB leaves & $144-217$ & 174 & 8.7 & $82-271$ & 214 & 19.0 \\
\hline & SB stems & $56-93$ & 78 & 4.6 & $52-87$ & 67 & 4.7 \\
\hline \multirow[t]{3}{*}{ SB/BFT } & SB leaves & $144-231$ & 186 & 10.0 & $208-263$ & 234 & 6.0 \\
\hline & SB stems & $69-95$ & 83 & 2.7 & $51-90$ & 74 & 4.0 \\
\hline & BFT & $147-209$ & 179 & 16.5 & $102-146$ & 131 & 8.9 \\
\hline \multicolumn{8}{|l|}{ Green ash } \\
\hline \multirow[t]{2}{*}{ BB } & BB leaves & $110-144$ & 124 & 4.0 & $70-93$ & 85 & 2.3 \\
\hline & BB stems & $65-87$ & 75 & 2.7 & $32-54$ & 41 & 2.3 \\
\hline \multirow[t]{3}{*}{$\mathrm{BB} / \mathrm{BFT}$} & BB leaves & $115-161$ & 133 & 5.3 & $0.08-105$ & 89 & 2.7 \\
\hline & BB stems & $65-92$ & 76 & 3.3 & $39-49$ & 43 & 1.3 \\
\hline & BFT & $172-203$ & 192 & 3.8 & $83-116$ & 150 & 4.5 \\
\hline \multirow[t]{2}{*}{ SB } & SB leaves & $137-171$ & 155 & 4.7 & 160-209 & 182 & 5.0 \\
\hline & SB stems & $66-84$ & 75 & 2.7 & $47-64$ & 55 & 1.7 \\
\hline \multirow[t]{3}{*}{ SB/BFT } & SB leaves & 144-184 & 165 & 5.0 & $170-246$ & 197 & 8.1 \\
\hline & SB stems & $75-93$ & 86 & 2.5 & $51-63$ & 55 & 1.8 \\
\hline & BFT & $172-212$ & 191 & 5.7 & $62-117$ & 92 & 6.4 \\
\hline
\end{tabular}

${ }^{a}$ Birdsfoot trefoil was not separated into leaf and stem fractions

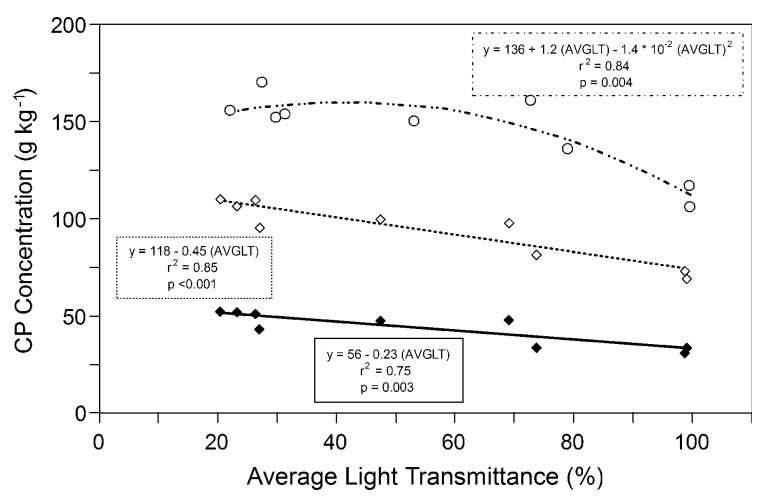

Fig. 2 Fitted curves for crude protein $(C P)$ concentration of big bluestem $(B B)$ leaves in June $\left(O_{-} \bigcirc\right)$ and September (Sept, $\diamond-\diamond)$ from monoculture plots, and BB stems in Sept $(\diamond-\diamond)$ from monoculture plots, at the Scotch pine location, in response to average light transmittance ( $A V G L T)$

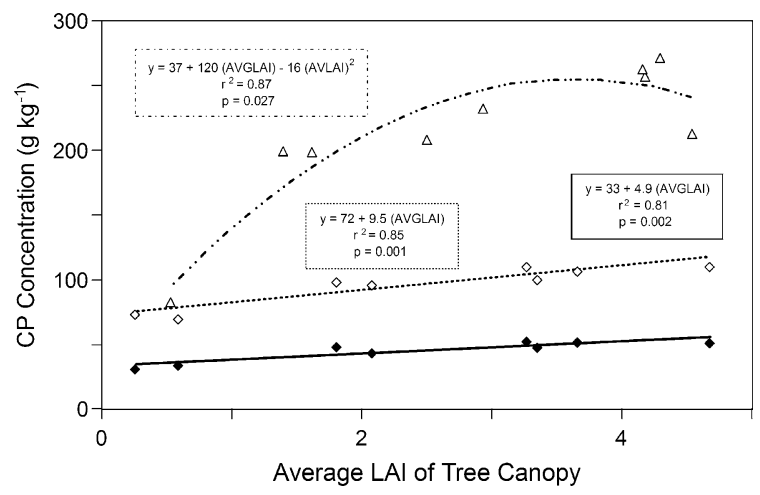

Fig. 3 Fitted curves for crude protein $(C P)$ content of big bluestem $(B B)$ leaves $\left(\diamond_{-} \diamond\right)$, BB stems $\left(\bullet_{-}\right)$, and smooth bromegrass $(S B)$ leaves $(\Delta-\Delta)$ in September (Sept) from monoculture plots, at the Scotch pine location, in response to average leaf area index (AVGLAI) 


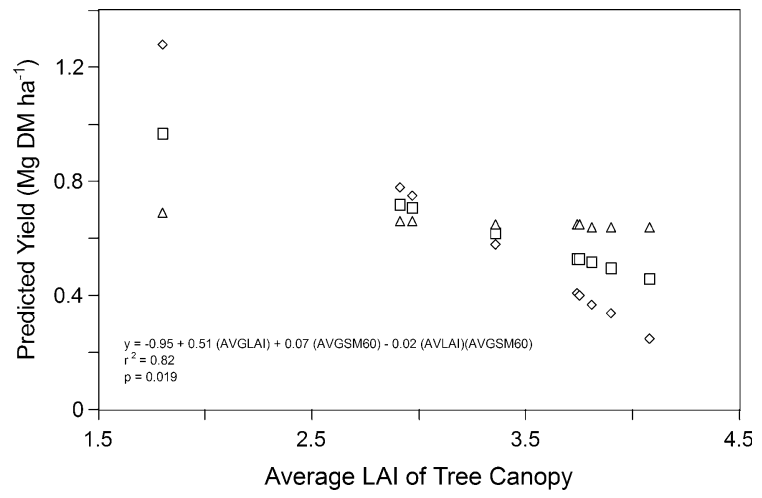

Fig. 4 Fitted curves for yield of big bluestem $(B B)$ in the BB/ birdsfoot trefoil plots in September (Sept) in response to average leaf area index (AVGLAI) and average soil moisture (AVGSM60) measured at the $0-60-\mathrm{cm}$ interval at the Scotch pine location. Predicted yield was based on the maximum $(\diamond)$, mean $(\square)$, and minimum $(\Delta)$ AVGSM values $(41.4,31.6$, and $22.8 \%$, respectively) as overstory tree LAI increased

June or September and any of the individual light main effects, AVGLT or AVGLAI were not significant. Characterizing canopy cover and light conditions in green ash plots was challenging because of the spatial irregularity of the overstory within each plot. Tree canopy was not uniformly distributed over a plot; therefore, LT measurements at plot centers or LAI measurements at plot corners did not necessarily characterize canopy cover or light conditions of a plot. The lack of correlation between light conditions and yield likely was related to this spatial irregularity of the overstory. Field observations, however, suggested that $\mathrm{BB}, \mathrm{SB}$, and BFT yields tended to respond to the range of canopy cover found over the study site.

Leaf and stem CP of $\mathrm{BB}$ and $\mathrm{SB}$ in June and September also were poorly correlated to light conditions of the deciduous tree overstory. There were a few instances, however, where light conditions did relate to $\mathrm{CP}$ (Table 4). Leaf CP of BB in the BB plots in June was predicted to increase by $9.0 \mathrm{~g} \mathrm{~kg}^{-1}$ as May LAI increased at increments of 0.5 (Table 4, Eq. 26). Leaf CP of SB in the SB plots in June was predicted to increase by $8.7 \mathrm{~g} \mathrm{~kg}^{-1}$ as May LAI increased at increments of 0.5 (Table 4, Eq. 28). In September, stem CP of SB in the SB/BFT plots was predicted to increase by $2.6 \mathrm{~g} \mathrm{~kg}^{-1}$ as July LAI increased at increments of 0.5 (Table 4, Eq. 30). The relatively poor correlation between light conditions and $\mathrm{CP}$ of the understory forage likely was caused by the spatial variability of the tree canopy within plot.

Interactions between light and soil moisture

There were light and SM interactions in predicting yield and $\mathrm{CP}$ of BB, SB, and BFT at both the Scotch pine and green ash locations. We hypothesized that yield of the understory forage plants would increase with increasing light levels when SM was favorable, but that yield would not necessarily respond to increasing light when SM was not favorable. There were several interactions between light variables and SM (Table 4, Eqs. 9, 27, 29) where SM was a significant part of equations explaining DM yield variability. September yields of BB in the BB/BFT plots at the Scotch pine location generally decreased as AVGLAI increased; however, AVGSM at the 0-60 cm interval influenced the rate of yield decline (Fig. 4). The greatest BB yield was at low LAI and maximum AVGSM (41.4\%). Yield of BB was predicted to decrease at the mean $(31.6 \%)$ and maximum SM with increasing LAI. Yield of BB was relatively low at the full range of LAI (1.8-4.1) at the minimum AVGSM (22.8\%). Soil moisture of plots at the minimum SM $(22.8 \%)$ was below the estimated PWP of $29.3 \%$, which suggests that physiological development and growth of BB would stop below the PWP and would not respond to light levels. Predicted yields at high LAI (4.1) were lower at maximum SM than the minimum. We did not collect complementary data that would help explain this result, but our visual observations supported this finding. We did not measure soil temperature but Wong and Wilson (1980) reported that soil temperatures decreased on average 3 and $2^{\circ} \mathrm{C}$ at depths of $5-\mathrm{cm}$ and 13-cm, respectively, as light levels decreased from full sunlight to $40 \%$ of full sunlight. Although we have no measure of this, wet, cool/cold soils favor some root and seedling diseases (Brady and Weil 2002). The wet soil found in some of the high canopy cover plots could have created favorable conditions for plant disease, resulting in very little plant growth-even when compared to plots with a combination of dry soil and high canopy cover. Although there were other interactions between light and SM in predicting yields of $\mathrm{BB}$ and SB, SM tended not to be a significant part of equations explaining yield variability in the understory of trees. 


\section{Summary and management implications}

Yields of BB, SB, and BFT frequently were correlated to overstory LAI and LT at the Scotch pine location. The relationship between yield and light was generally linear with yield increasing incrementally as light levels increased. The infrequent occurrence of quadratic responses indicates that yield thresholds generally were not reached where yield was no longer affected by changing light conditions. The increase in BB yield as light increased was not surprising because BB is a warm-season species and does not reach a light saturation point where $\mathrm{CO}_{2}$ uptake is limited (Hopkins 1999). The linear relationship between SB yields and light levels demonstrates that light saturation, even at full sunlight, of a cool-season grass such as SB does not occur on a stand basis. Within the canopy of a SB stand, most leaves are shaded by other SB leaves; therefore, light saturation for the stand as a whole does not occur and plant production increases incrementally with increasing light. Relationships between light and BFT yield in the BB/BFT or SB/BFT plots were quadratic in most cases. The response of total plot yield was similar to those already described for the $\mathrm{BB}, \mathrm{SB}$, and BFT relationships. Yield of BB, SB, and $\mathrm{BFT}$ at the green ash location were not highly correlated to the narrower range of light levels; however, a few significant relationships were found.

Crude protein of leaves and stems of BB and SB and whole-plant BFT generally decreased as light levels increased and was predicted to be the lowest for all three species at full sunlight. The relationship between light and CP was not consistently linear or quadratic. Plants growing in the shade tended to be at earlier stages of development with lower yields and higher CP. At the Scotch pine location, AVGLT for May and June was a good predictor of June BB yield as well as CP of BB leaves and stems (Table 4). Such relationships were found in a few instances where yield and leaf CP and/or stem CP were predicted effectively by the same measure of light (e.g., LAI, AVGLAI, LT, or AVGLT).

The relationship between most measures of light and yield or CP was not significant at either location. The reasons for this can be explained by a number of design, methodology, and environment factors. Individual month measurements generally were not correlated to yield or $\mathrm{CP}$ and infrequently explained a significant portion of the variability in yield or $\mathrm{CP}$ in June or September. Average LAI or LT was usually the light-related variable that was correlated to June or September yields or CP. June or September yields and CP apparently were the result of the cumulative effect of light conditions rather than of a particular month.

Measuring light quality was not part of this study; however, light quantity and quality affects plant morphology and dry matter allocation (Belesky 2005) and carbohydrate partitioning (Frank and Hofmann 1994). As a result, far-red enriched light under tree canopies likely impacts forage yield and nutritive value. Conifers potentially provide much less far-red enrichment compared to deciduous trees because they reflect and scatter much less far-red light (Gates 1980). Awada et al. (2003) completed an accompanying study at the green ash location, during the same time frame as this study, to determine the physiological responses of BB and SB to various canopy levels in May and July. Chlorophyll content and leaf $\mathrm{N}$ of SB was greater than BB under all light levels. As overstory canopy cover and shade increased, stomatal conductance and dark respiration of both species declined. Species response to increasing shade showed an increase in specific leaf area, with a greater increase for SB at all light levels than for BB (Awada et al. 2003).

Results of this study demonstrate that measures of light can be used to predict forage yield and CP in the understory of Scotch pine and, to a lesser extent, green ash trees. Yield and $\mathrm{CP}$ of the understory forages was more commonly correlated to the LT measurements; however, there were acceptable equations with LAI as the independent variable. The two methods and instruments used as measures of light conditions under a tree canopy probably are not appropriate for most landowners operating silvopasture systems. The instruments are relatively expensive and the methods require close attention to detail, including the timing and location of measurements. The LT equipment and methods used in this study required measurements be taken at solar noon on sunny days and between the trees in eight different directions (Constabel and Lieffers 1996). Overstory LAI is a relatively rapid measure of canopy cover, but requires taking measurements on cloudy days, or at dawn, when the azimuth angle of the sun is no greater than $76^{\circ}$ (Gower and Norman 1991). The LI-COR 
LAI-2000 also is a very complex instrument and an understanding of the physics behind the instrument is crucial to acquiring data that is reliable. Other simpler methods of estimating green crown length or area and diffuse non-intercepted radiation could be identified and adapted to the needs of producers in silvopasture systems (Addendum to Water Quality Monitoring Technical Guide Book 2000).

There does not appear to be an optimum time during the growing season to measure overstory LAI or LT. Light measurements averaged over several months best predicted yield and CP. Two or more measures of LAI or LT distributed over time are likely to be a better predictor of yield and $\mathrm{CP}$ of the species because of a number of reasons. Over a period of 2 months or more, while understory plants are growing, the overstory LAI and/or LT changes because of canopy development dynamics and changes in sunlight incidence. This is especially true at the green ash location where the canopy was not fully established until mid- to late May. Plant growth during this time is a result of the integration of these changes rather than light conditions at a specific point in time. There also is error associated with each measurement point in time; therefore, multiple measurements should provide (1) a more accurate estimate of light conditions rather than a single measurement and (2) a better estimate of light conditions when dealing with irregular tree canopies. Results of this study indicate that there is not a single point in time that represents the most opportune time to measure overstory LAI or LT. This study is similar to what has been found in other regions, that additional studies on silvopasture systems in the central Great Plains region are warranted.

Acknowledgments The authors express appreciation to Richard Carmen, Michael Guderjan, Jeremy Hiller, Ann Koehler, Dr. Lowell Moser, Dr. David Nielsen, Elena Perry, and Dr. Michele Schoeneberger for their excellent technical assistance during the experiment. Without the assistance of these individuals, the completion of this research would not have been possible. This project was supported in part by the USDA Forest Service, Rocky Mountain Research Station, the USDA National Agroforestry Center, the McIntyre Stennis Forestry Research Fund, and the Center for Great Plains Studies.

\section{References}

Addendum to Water Quality Monitoring Technical Guide Book (2000) Chapter, 14 Stream shade and canopy cover monitoring methods. http://www.krisweb.com/biblio/gen_ oregon_xxxx_1999_wqmanualchap14.pdf. Cited 25 Oct 2008

Allard G, Nelson CJ, Pallardy SG (1991) Shade effects on growth of tall fescue: I. Leaf anatomy and dry matter partitioning. Crop Sci 31:163-167

Awada T, Perry MEL, Schacht WH (2003) Photosynthetic and growth responses of the $\mathrm{C}_{3}$ Bromus inermis and the $\mathrm{C}_{4}$ Andropogon gerardii to tree canopy cover. Can J Plant Sci 83:533-540

Belesky DP (2005) Dactylis glomerata growing along a light gradient: I. Dry matter production and partitioning in plants establishing in spring or late summer. Agrofor Syst 65:9198. doi:10.1007/s10457-004-5726-X

Beuselinck PR, Grant WF (1995) Birdsfoot trefoil. In: Barnes $\mathrm{RF}$ et al (eds) Forages volume 1: an introduction to grassland agriculture. Iowa State University Press, Ames, pp 237-248

Björkman O (1981) Responses to different quantum flux densities. In: Lange OL et al (eds) Physiological plant ecology, volume 1. Responses to the physical environment. Springer, Berlin, pp 57-107

Boardman NK (1977) Comparative photosynthesis of sun and shade plants. Annu Rev Plant Physiol 28:355-377. doi: 10.1146/annurev.pp.28.060177.002035

Brady NC, Weil RR (2002) The nature and properties of soils, 13th edn. Prentice Hall, Upper Saddle, pp 487-488

Buxton DR, Casler MD (1993) Environmental and genetic effects on cell wall composition and digestibility. In: Jung HG, Buxton DR, Hatfield RD, Ralph J (eds) Forage and cell wall structure and digestibility. American Society of Agronomy, Crop Science Society of America, and Soil Science Society of America, Madison, pp 685-714

Buxton DR, Fales SL (1994) Plant environment and quality. In: Fahey GC Jr et al (eds) Forage quality evaluation and utilization. ASA, CSSA, and SSSA, Madison, pp 155-199

Casler MD, Calrson IT (1995) Smooth bromegrass. In: Barnes $\mathrm{RF}$ et al (eds) Forages volume 1: an introduction to grassland agriculture. Iowa State University Press, Ames, pp 313-324

Clason TR (1995) Economic implications of silvipastures on southern pine plantations. Agrofor Syst 29:227-238. doi: 10.1007/BF00704870

Clason TR, Sharrow SH (2000) Silvopasture practices. In: Garrett HE et al (eds) American agroforestry: an integrated science and practice. ASA, Madison, pp 119-147

Constabel AJ, Lieffers VJ (1996) Seasonal patterns of light transmission through boreal mixedwood canopies. Can J Res 26:1008-1014. doi:10.1139/x26-111

Frank AB, Hofmann L (1994) Light quality and stem numbers in cool-season forage grasses. Crop Sci 34:468-473

Fulbright TE, Redente EF, Hargis NE (1982) Growing Colorado plants from seed: a state of the art: volume 2: grasses and grasslike plants.. US Department of the Interior, Fish and Wildlife Service, Washington, DC, p 113

Garrett HE, Kurtz WB (1983) Silvicultural and economic relationships of integrated forestry-farming with black walnut. Agrofor Syst 1:245-256. doi:10.1007/BF00130 610

Gates DM (1980) Biophysical ecology. Springer, New York, p 611 
Gold MA, Rietveld WJ, Garrett HE, Fisher RF (2000) Agroforestry nomenclature, concepts, and practices for the USA. In: Garrett HE et al (eds) American agroforestry: an integrated science and practice. ASA, Madison, pp 63-77

Gower ST, Norman JM (1991) Rapid estimation of leaf area index in conifer and broad-leaf plantations. Ecology 72:1896-1900. doi:10.2307/1940988

Henderson MS, Robinson DL (1982) Environmental influences on fiber component concentrations of warm-season perennial grasses. Agron J 74:573-579

Hopkins WG (1999) Introduction to plant physiology, 2nd edn. Wiley, New York

HPRCC (High Plains Regional Climate Center) (2002) Historical climate data summaries. http://www.hprcc.unl.edu/ data/historical. Cited 12 Mar 2002

Hunt LA, Jones JW, Thornton PK, Hoogenboom G, Imamura DT, Tsuji GY, Balas S (1994) Accessing data, models and application programs. In: Hoogenboom G et al (eds) DSSAT v3, vol 4. University of Hawaii, Honolulu, pp 21-110

Jones JW, Tsuji GY, Hoogenboom G, Hunt LA, Thornton PK, Wilkens PW, Imamura DT, Bowen WT, Singh U (1998) Decision support system for agrotechnology transfer: DSSAT v3. In: Tsuji GY, Hoogenboom G, Thornton PK (eds) Understanding options for agricultural production. Kluwer Academic Publishers, Norwell, pp 157-177

Kephart KD, Buxton DR (1993) Forage quality responses of $\mathrm{C}_{3}$ and $\mathrm{C}_{4}$ perennial grasses to shade. Crop Sci 33:831-837

Kephart KD, Buxton DR, Taylor SE (1992) Growth of $\mathrm{C}_{3}$ and $\mathrm{C}_{4}$ perennial grasses under reduced irradiance. Crop Sci 32:1033-1038

Langilee JE, Calder FW (1971) Effect of harvesting practices on foliage and root development, digestibility, cold hardiness and nodulation of birdsfoot trefoil. Can J Plant Sci 51:499-504

Lewis CE, Burton GW, Monson WG, McCormick WC (1983) Integration of pines, pastures, and cattle in south Georgia, USA. Agrofor Syst 1:277-297. doi:10.1007/BF00155936

Lewis CE, Tanner GW, Terry WS (1985) Double vs. singlerow pine plantations for wood and forage production. S J Appl For 9:55-61

Lin CH, McGraw RL, George MF, Garrett HE (1999) Shade effects on forage crops with potential in temperate agroforestry practices. Agrofor Syst 44:109-119. doi:10.1023/ A: 1006205116354

Marten GC, Jordan RM (1979) Substitution value of birdsfoot trefoil for alfalfa-grass in pasture systems. Agron J 71:55-59

McGraw MC, Stamps WT, Houx JH, Linit MJ (2008) Yield, maturation, and forage quality of alfalfa in a black walnut alley-cropping practice. Agrofor Syst 74:155-161. doi: 10.1007/s10457-008-9162-1
Misra G, Singh KP (1982) Effect of soil moisture and clipping on the nutrient $(\mathrm{N}, \mathrm{P}$, and $\mathrm{K})$ concentration, uptake and use efficiency in one temperate and 2 tropical grasses. Plant Soil 69:413-421. doi:10.1007/BF02372462

Moser LE, Hoveland CS (1996) Cool-season grass overview. In: Moser LE et al (eds) Cool-season forage grasses. Agron Monogr 34. ASA, CSSA, and SSSA, Madison, pp 1-14

Moser LE, Vogel KP (1995) Switchgrass, big bluestem, and indiangrass. In: Barnes RF et al (eds) Forages volume 1: an introduction to grassland agriculture. Iowa State University Press, Ames, pp 409-420

Murchie EH, Horton P (1997) Acclimation of photosynthesis to irradiance and spectral quality in British plant species: chlorophyll content, photosynthetic capacity and habitat preference. Plant Cell Environ 20:438-448. doi:10.1046/ j.1365-3040.1997.d01-95.x

Pearson HA, Whitaker LB (1974) Forage and cattle responses to different grazing intensities on southern pine ridge. $\mathrm{J}$ Range Manage 27:444-446. doi:10.2307/3896718

Perry MEL (2004) Tree canopy effect on grass and grass/birdsfoot trefoil mixtures in eastern Nebraska. M.S. Thesis, Department of Agronomy, University of Nebraska, Lincoln, NE, USA

SAS Institute Inc (1999) SAS/STAT user's guide, version 8. Cary, NC, USA

Stubbendieck J, Hatch SL, Butterfield CH (1997) North American range plants, 5th edn. University of Nebraska Press, Lincoln

Undersander D, Greub L, Leep R, Beuselinck P, Wedberg J, Smith D, Kelling K, Doll J, Cosgrove D, Grau C, Peterson S, Wipfli M English J (1993) Birdsfoot trefoil for grazing and harvested forage. North Central Region Ext. Pub. 474. North Central Region Ext., Madison, WI, USA

Waller SS, Lewis JK (1979) Occurrence of $\mathrm{C}_{3}$ and $\mathrm{C}_{4}$ photosynthetic pathways in North American grasses. $\mathrm{J}$ Range Manage 32:12-28. doi:10.2307/3897378

Weaver JE (1965) Native vegetation of Nebraska. University of Nebraska Press, Lincoln

Wilson JR (1983) Effects of water stress on in vitro dry matter digestibility and chemical composition of herbage of tropical pasture species. Aust J Agric Res 34:377-380. doi:10.1071/ AR9830377

Wilson JR (1984) Environmental and nutritional factors affecting herbage quality. In: Hacker JB (ed) Nutritional limits to animal production from pastures. Commonwealth Agricultural Bureaux, Slough, pp 111-131

Wong CC, Wilson JR (1980) Effects of shading on the growth and nitrogen content of green panic and Siratro in pure and mixed swards defoliated at two frequencies. Aust J Agric Res 31:269-285. doi:10.1071/AR9800269 